\title{
Knowledge Transfer \\ in the Automotive Industry: The Case of JICA's Project for Automotive Supply Chain Development in Mexico
}

\author{
Transferencia de conocimiento en la industria \\ automotriz: el caso del proyecto de JICA para el \\ fortalecimiento de la cadena de proveeduría del sector \\ automotriz en México
}

DOI: $10.32870 /$ mycp.v8i23.609

Leo Guzman-Anaya ${ }^{1}$

\begin{abstract}
The automotive industry is considered a source for economic development in both developed and developing countries. However, endogenous firms in developing countries may not reap the positive externalities of entering global production chains due to their technological and knowledge deficiencies. This is particularly noticeable for Japanese production chains that demand high-quality parts and components and favors the procurement from companies from the same business group, limiting the opportunities for local firms. Training may help reduce this gap by transferring both tacit and explicit knowledge. This analysis provides evidence that institutions such as government agencies may
\end{abstract}

affect the transfer of knowledge to local firms at the micro-level via training. The results from qualitative case studies show benefits from a training project carried out by the Japan International Cooperation Agency (JICA) in Mexico. Participating firms experienced overall growth and improvements in their quality and productivity indicators, allowing them to obtain certifications, increase their customer base and diversify to new markets. The knowledge acquired was internalized and diffused throughout the firms and in certain cases spilled-over to other production lines and other companies.

Keywords: training, knowledge transfer, knowledge spillovers, automotive industry, Mexico.

Artículo recibido el 13 de noviembre de 2018 y dictaminado el 05 de febrero de 2019.

1. University of Guadalajara, Center for Economic and Administrative Sciences. Periferico Norte 799 C.P. 45100, Zapopan, Jalisco, Mexico. ORCID: 0000-0002-5682-3175 E-mail: leo. guzman8@gmail.com 


\section{Resumen}

La industria automotriz es considerada una fuente para el desarrollo económico tanto en países desarrollados como en vías de desarrollo. Sin embargo, las firmas endógenas en países en vías de desarrollo pueden no recibir las externalidades positivas de ingresar en cadenas de producción global debido a sus deficiencias tecnológicas y de conocimiento. Esta situación es notable para cadenas de producción japonesa, las cuales demandan partes y componentes de alta calidad y favorecen la proveeduría de empresas pertenecientes a su mismo grupo económico, limitando las oportunidades para empresas locales. La capacitación y el entrenamiento pueden reducir la brecha tecnológica por medio de transferencia de conocimiento tácito y explícito. Este análisis presenta evidencia del rol que ejercen las agencias gubernamentales y la forma en que pueden afectar la transferencia de conocimiento a empresas locales por medio de entrenamiento. Los resultados presentados son de estudios de caso cualitativos y muestran beneficios de un proyecto de entrenamiento y capacitación implementado por la Agencia Japonesa de Cooperación Internacional (JICA por sus siglas en inglés) en México. Las empresas participantes del proyecto mostraron crecimiento y mejoras en sus indicadores de calidad y productividad, lo que les permitió obtener certificaciones, incrementar su cartera de clientes y diversificar a nuevos mercados. El conocimiento adquirido pudo ser internalizado y difundido dentro de las empresas y en algunos casos se transfirió a otras líneas de producción y otras compañías.

Palabras clave: entrenamiento, transferencia de conocimiento, derrames de conocimiento, industria automotriz, México.

\section{Acknowledgements}

This paper was written with information collected during visits to Mexican and Japanese companies that participated in JICA's "Project for Automotive Supply Chain Development" in Guanajuato, Mexico. I am heavily indebted to Mr. Keiji Katai, Mr. Kazuki Otsuka and Mr. Alejandro Rios from JICA for allowing me to take part in the company visits and interviews that made possible this research paper. Also, I am indebted to two anonymous referees for providing insightful comments and suggestions that resulted in this paper. The usual disclaimer applies.

\section{Introduction}

For many countries, the automotive industry has been regarded as a driver of growth, a source of employment, technological knowledge and a stimulus to other industries through backward linkages. However, only a handful of developing countries have achieved the development of an internationally competitive automotive industry (Athukorala \& Kohpaiboon, 2011). The development of the automotive industry requires skilled labor and a strong supporting industry to provide from 20,000 to 30,000 parts and components. The supplier firms and the assembly plants work interconnected and create 
externalities to each other, but this development takes time because local firms need a prolonged process of accumulation of knowledge and capabilities, especially with regards to human capital formation and knowledge and technology adoption and diffusion (Hosono, 2015).

The development of the local automotive supporting industry can be achieved via training. For example, Thailand stands out as a case where the training of engineers and skilled/semi-skilled workers was crucial for the development of a competitive and inclusive automotive industry (Hosono, 2015). Yamashita (2004) mentions that the local content requirements incentivized foreign firms to offer continuous technological support to local suppliers and the Thai government offered education and training to transfer specific requested industrial skills, resulting in the development of local automotive suppliers and a pool of skilled technicians and engineers.

For the case of Japanese Foreign Direct Investment, it has been argued that the particular characteristics in its global-local interlinked network, what is known as the keiretsu (a network in the network), limits linkages with local firms (Irawati, 2012). Also, suppliers from developing countries face additional difficulties due to the technological gap that limits their capabilities to offer the required quality in the parts and components. Hoshino (2015) argues that the catching-up process for these firms depends on three conditions: industry-level conditions, firm-level capabilities and institutional settings. However, the sectoral system approach envisions an economic sector as a set of activities associated with product groups that meet emerging or existing demand. In this sense, the sectoral system framework focuses on three main dimensions that enable economic change and innovation and are key to the catching-up of firms and countries: knowledge and technological domains, actors and networks and institutions (Malerba, 2018).

During the 1980's Japanese automotive industry began to move production abroad, where the lean production system required a specific type

2. The "Keiretsu" is a Japanese term to refer to a group of companies with closely related commercial and participation relationships. The firms usually produce a wide range of products and are centered on a bank and trading company. Another characteristic is that each firm owns a small proportion of shares of other companies in the group. Also, as Irawati (2012) points out for the case of Japanese automobile companies, the keiretsu model has been important to develop large Japanese auto firms since banks have provided necessary financial funds and through mutual ownership with other automobile firms there has been cooperation and assistance to deal with technological change and adoption of new management systems. 
of industrial organization. The case of the U. S. and Southeast Asia stand out since in both experiences local suppliers were not available in early stages to provide procurement for Japanese final assemblers. For the U. S., what

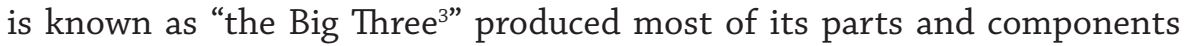
in-house, limiting the development of a supplier base; while for the case of Southeast Asia, the quality and technological levels of local suppliers were of poor standards. As a result, Japanese OEMs requested their suppliers in Japan to establish production facilities in the U. S. and in several Southeast Asian countries, allowing the transplanting and translating of important features of Japanese firms into the host country (Smitka, 1991).

Recently, Japanese Foreign Direct Investment (JFDI) flows to Mexico have increased significantly since the implementation of the Mexico-Japan Economic Partnership Agreement (EPA) in 2005 (see figure 1). Around 70\% of the FDI flows have concentrated in the automotive industry and in the western region of Mexico including the states of Aguascalientes, Guanajuato, Jalisco and Queretaro. The region has been strategically chosen by Japanese firms due to several factors. First, there are favorable conditions in the region in terms of infrastructure, competitive production costs and a qualified labor force that allow the establishment of a production base for exporting purposes. Second, despite that most of the production ends up in foreign markets, the internal market is expanding with an increasing demand for automotive products. Third, there have been favorable public policies set forward by the state and local governments in terms of labor conditions and fiscal incentives to attract Japanese firms in the region (Lugo-Sanchez, 2018).

3. The Big Three refers to the U. S. largest automotive manufacturers, including General Motors, Ford and Fiat Chrysler. 
JFDI flows to Mexico in constant 2013 Million USD (2005-2017)

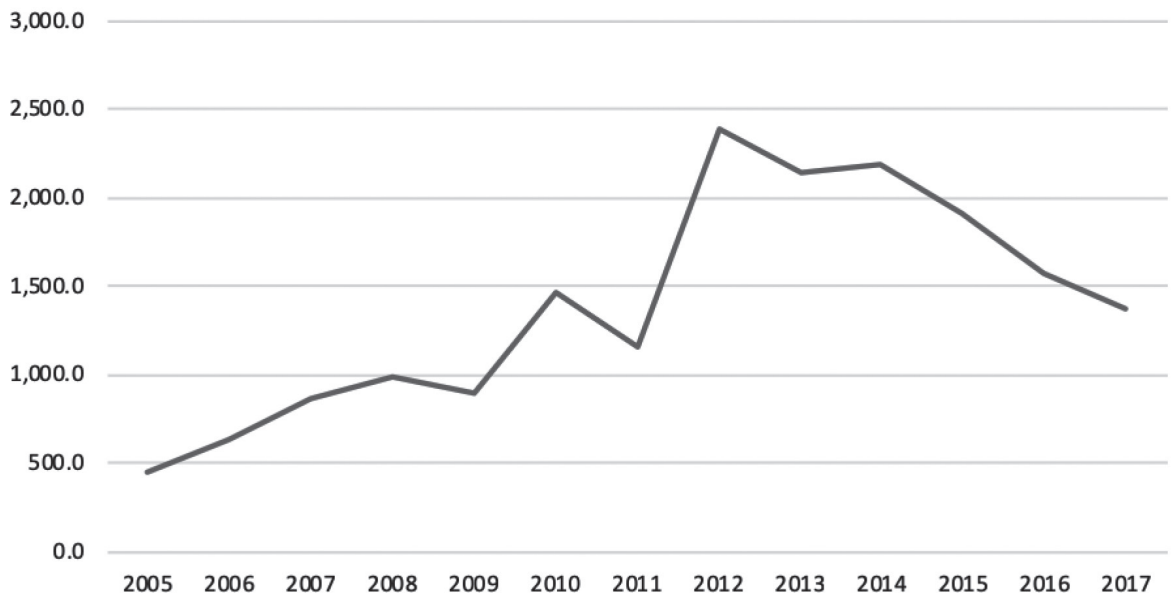

Source: Author's elaboration with data from Secretaría de Economía (2018).

Despite a growing interest of Japanese-affiliated companies to establish in automotive related industries, Mexico has failed to take full advantage of these opportunities due to insufficient labor and technology (Japan International Cooperation Agency, 2017). Local firms in particular have failed to enter global production chains due to insufficient technological and quality capacities. These constraints create high entry barriers to local firms in the Japanese global production networks that have incentivized Japanese companies to establish their production chain in Mexico, primarily in the Tier-1 level of procurement with an increasing presence in the Tier-2 level. At the moment, there are opportunities for local suppliers to enter automotive production chains at the Tier- 2 and Tier-3 levels since more than half of the inputs are still imported.

In this sense, the present research analyzes the effects from organizational training, which in turn may open new business opportunities to local firms in Japanese automotive production chains by reducing the knowledge gap; particularly training may transfer both tacit and explicit knowledge that improves the quality and productivity of firms allowing an expansion in sales, new customers, new products and the achievement of industry certifications that sets them in a better position to be suppliers of competitive multinational 
firms. The focus in the analysis is set on firms in Guanajuato that participated in the "Project for Automotive Supply Chain Development in Mexico".

The research employs individual firm case studies and seeks to provide empirical evidence on the gains and possible struggles observed after the implementation of JICA's training program. Particularly, the research centers on business expansion, and changes in quality and productivity. Also, interest is set on the knowledge transfer mechanisms implemented by local firms to acquire tacit or explicit knowledge from the Japanese training program.

The paper is organized as follows: The following section presents an overview of JICA training programs in diverse parts of the world and for the specific case of the automotive industry and Mexico. Section three examines the empirical and theoretical literature on training programs, highlighting previous research on JICA development programs and cases for the automotive industry. Section four indicates the empirical methodology followed in this analysis and the results obtained from the individual cases studies. Section five concludes.

\section{JiCA Training Programs}

According to the Japan International Cooperation Agency (2017), in 2016 Japan ranked fourth as an overall net contributor of ODA (Official Development Assistance) with Us $\$ 10,331.42$ million, only below the United States, Germany and the United Kingdom. However, from the members of the Development Assistance Committee (DAC) of the Organization for Economic Co-operation and Development (OECD), Japan ranks 20th among the 29 members contributing only with $0.20 \%$ of Gross National Income (GNI) to ODA. Despite this, JICA is in charge of administering Japan's ODA and is considered the world's largest bilateral aid agency with presence in 150 countries. The main goal of JICA is to support socioeconomic development in developing countries by offering a variety of assistance programs such as technical cooperation, investment cooperation, and grants.

As part of JICA's ODA, the agency has offered Training Programs (TPs) to developing countries since Japan joined the Colombo Plan in 1954. Since then, according to the Japan International Cooperation Agency (2016), over 310,000 trainees from 198 countries have benefited from one of JICA's programs in a variety of areas. In 2016, JICA counted with 549 technical cooperation ongoing projects in 88 countries (Japan International Coopera- 
tion Agency, 2017). Traditionally, JICA's TPs had the goal to impact trainees at the individual level; however, since 2012 the agency's goals have shifted to enable environments that impact at the organizational level (Mikami \& Furukawa, 2014).

Mexico ranks in the top ten countries of JICA's training assistance between 1970 and 2012, with total training participants oscillating between 100 and 250 trainees per year (Japan International Cooperation Agency, 2016). The EPA establishes Japan's Country Assistance Program for Mexico and “industry promotion" has been regarded as a top priority area for operation. The Japanese government generated a "Program to Strengthen the Competitiveness of SMEs and Supporting Industries" seeking to provide technical support to promote new technology adoption from Mexican SMEs. Particularly, JICA's ODA assistance program for Mexico has focused on cultivating highly skilled Mexican engineers needed for the automotive industry, while also improving the quality, productivity and competitiveness of endogenous supporting small and medium size firms (Japan International Cooperation Agency, 2017).

Several projects have been launched by JICA in recent years to strengthen local workforce and suppliers, for example the "Project for Human Resource Development for the Automotive Industry in El Bajio of Mexico", the "Project on Automotive Cluster Promotion" and the "Project for Automotive Supply Chain Development in Mexico" (hereafter PASCDM). The PASCDM was created to strengthen and develop the local supplier base in the automotive industry, expecting improvements in quality, productivity and competitiveness that would enable local suppliers to form part of Japanese automotive supplier chains in Mexico.

The PASCDM was developed in three phases from November 2012 to November 2015 with the participation of 30 local firms from the states of Queretaro, Guanajuato and Nuevo Leon. These states were selected due to the strategic location of these entities for the Mexican automotive industry and represent key locations for Japanese automotive firms. Nuevo Leon has a long tradition of automotive industry manufacturing, and Guanajuato has attracted the location of Japanese Original Manufacturers (OEMs) which in turn has stimulated the location of Japanese Tier-1 firms in both Guanajuato and Queretaro. The main goal of the project was to strengthen and develop the Tier- 1 and Tier- 2 suppliers in the aforementioned states. The idea behind the project was to train Mexican suppliers of automotive parts and components 
(Tier-2 producers) to adopt Kaizen ${ }^{4}$ activities in terms of quality, costs and delivery times. Also, the project trained Mexican entrepreneurs and local government officials to help them understand Japanese production and business practices in general and Kaizen philosophy in particular.

In a previous study Guzman-Anaya (2018) analyzes the results from the PASCDM using the project's reports and found positive effects TPs on the productivity of local firms in all states. However, the research methodology followed in the previous study did not allow a deep understanding of the benefits and disadvantages from the project as well as the knowledge transfer mechanisms which might be better analyzed using individual case studies. Also, the research used data gathered shortly after the completion of the project so quantitative results in some cases were not observed, since significant changes in the organization take time to develop. Nakano, Tsusaka, Aida, and Pede (2015) point out that the impact evaluation of TPs should not be conducted in the short-run, instead it should be studied in the medium or long-term (at least a few years after implementation), in order to fully capture the spillover effects and benefits from training. In this sense, the current research seeks to revise via case studies the impact of the PASCDM on the firms that participated in the TPs in terms of the benefits and difficulties obtained and analyze the knowledge acquisition and diffusion methods of the trained firms.

\section{Literature Review}

Knowledge is considered non-rival and cumulative good. It is usually categorized in various ways, for example in terms of tacit or explicit knowledge. Nonaka and Takeuchi (1995) consider tacit knowledge as "know-how", in other words the knowledge that is embedded in a person through experience and learning-by-doing. This type of knowledge is difficult to extract and codify. On the other hand, explicit knowledge is regarded as "know-that" and may be codified, digitized and preserved in books, manuals and other type of documents. In this sense, Urata (1996) argues that training is effective in

4. The term "Kaizen" refers to a process of continuous improvement that involves all elements of an organization. It is considered a concept that reflects the best Japanese management practices that helped boost Japanese firms after World War II to world class competitiveness levels during the 1980s. For further information see Imai (1986). 
transferring both tacit and explicit knowledge and that some products from training such as manuals further transfer explicit knowledge. Furthermore, the Japanese production system favors the transfer of tacit over explicit knowledge.

Rivera (2002) mentions that the transfer of knowledge and technology may take place using formal and informal channels. The formal mechanisms include the selling or contracting of technology through licensing, patents, packages, trademarks, turn-key plants, consulting and technical services. However, for the case of developing countries, this channel imposes a series of restrictions and barriers for domestic enterprises to acquire new technology. It is argued that informal mechanisms have a larger impact for developing countries' domestic firms. The informal channels include reverse engineering, personal contacts, study groups between academic and private corporations, involuntary leakage of technical information and training of employees and local suppliers.

United Nations Conference on Trade and Development (2014) mentions that host-country might also offer financing support, matching services, partnerships and alliances, support for purchase of licensing and equipment, and training. From a survey to 41 agencies from developed countries, 19 provided support for TPs and four of these deployed their programs in developing countries to train workers. The study highlights the case of Japan and the training provided through the Japan International Training Organization (JITCO), where international workers are invited to undergo training at Japanese companies for one year.

Similarly, the Japan International Development Organization provides equity participation and loan facilities for joint ventures between private Japanese and local enterprises. These projects are long-term with social or environmental value where the new established firm should use proven technology. Finally, JICA is responsible for technical cooperation within Japan's ODA program. The main goal is to transfer knowledge and technology to developing countries to stimulate socio-economic development. JICA uses training to transfer knowledge to administrators, technicians and researchers. Other programs include the youth invitation program; dispatch of technical cooperation experts; project-type technical cooperation; development studies; grant aid to developing countries; Japan Overseas Cooperation Volunteers and Senior Volunteers programs. 
Empirical studies evaluating the impact of TPs have followed an inter-disciplinary approach from areas such as labor economics, business administration and development studies (Mikami \& Furukawa, 2014). Labor economics studies have focused on the interactions between firms and employees and the general cots of training. It is argued that through training, employees invest in their human capital stock increasing their productivity; however, the offering of training creates a conflict of interests between employees that received the training and the company that paid for their instruction. On the one hand, trained employees have an incentive to leave the firm seeking higher wages and on the other firms seek to recover the benefits from trained employees. Additionally, employee training might create tensions among competing firms since skilled workers might be seen as a common good, creating incentives for free-riding. The main approach from labor economics studies is to find the optimal levels and equilibrium scenarios for training (Acemoglu, 1997; Acemoglu \& Pischke, 1998; Boom, 2005).

Development studies have focused on the donor-lending scenario in developing countries and the efficiency and effectiveness of training. Several studies have researched the training of high-level technical and managerial skills in the public sector and the brain drain problem of locally and internationally trained civil workers (Tessema, Winrow \& Teclezion, 2012).

From the business administration perspective, research has analyzed the outcomes from training at the organizational level. One approach has been to observe improvements in firm performance and innovation (Bartel, 1994; Huang, 2001; Almeida \& Carneiro, 2009; Dumas \& Hanchane, 2010; Chen, Hsu \& Huang, 2013); another approach has centered on the internal or external conditions than enable training effectiveness (Nikandrou, Apospori, Panayotopoulou, Starvrou, \& Papalexandris, 2008).

There have been longstanding criticisms on the effectiveness of TPs. Critics argue that doubts emerge if training participants learn anything from the courses, especially when there is a lack of clear training policies and poor training participant selection. Also, even when trainees are effectively transferred knowledge, there seems to be tendency for them to leave the organization after training, searching for higher wages and better working conditions leaving the organizations worst off and aggravating the brain drain problem in developing countries. Mikami and Furukawa (2014) argue that three factors seem to matter in training effectiveness, including trainee characteristics, training design and work environment. 
Positive results from Japan's ODA have been documented for developing countries. Sahoo and Bishnoi (2016) report the impact of Japanese ODA in the form of transport infrastructure in India. The study mentions that Japanese ODA and technology have changed the way of life and urban landscape in several Indian cities, reducing trade costs, increasing employment, income and overall living standards.

Similarly, several studies have analyzed the impact of JICA's TPs. Nakano et al. (2015) researched the productivity gains from JICA training schemes on new rice cultivation technologies in Tanzania. The results showed that trained farmers improved their productivity and the knowledge spilled-over to non-trained farmers through social networks and observation resulting also in productivity gains. Kijima (2018) analyzed the short and long-term spillover effects from JICA lowland rice farming training project for sustainable irrigated agricultural development in Eastern Uganda. The results showed that the TP created knowledge and technology spillovers to trainees and non-participants within the community. Specifically, the study shows that in the short-term, participants of the project adopted the improved cultivation practices and this knowledge spilled-over to non-participants in the long-term. This resulted in an overall increase of total rice production for households of participants and non-participants. Mikami and Furukawa (2014) analyzed the impact of JICA training of public servants and found that efficient bilateral communication between trainees and their dispatch organization plays a key role in successfully transferring individual-level learning to the organizational-level.

For the automotive industry, the JICA "Project for Technical Support to Auto Parts Manufacturing Industry" in Lahore and Karachi, Pakistan, achieved the improvement of quality, productivity and competitiveness of auto parts suppliers through technical support from Japanese experts. Similarly, the program launched between JICA and the Automotive Industry Development Centre in South Africa had the mission to dispatch Japanese automotive experts providing technical expertise and training to develop local automotive manufacturing firms. The project showed positive outcomes in terms of supplier development in the automotive industry.

Irawati (2012) considers the Japanese lean production system to be the most important comparative advantage that can transform a host country via knowledge and technology transfer. However, the lean production system must be transferred not only in terms of production facilities and processes, 
but also in terms of organizational structure (Fujimoto, 2007). The process of knowledge transfer is thus a dynamic process that evolves into a network with intensive interaction between producers and recipients of knowledge or technology.

As important as transferring explicit knowledge, tacit knowledge is crucial for organizational learning in the automotive industry. Irawati (2012) mentions that tacit knowledge is increasingly being acquired within automotive firms through activities in the form of product design, production engineering, quality control, education and staff training, research and the development of prototypes or pilot plans. Tacit knowledge is primarily acquired via trial and error or experience (Nonaka et al., 2000).

The process of technological and knowledge transfer is usually regarded as an interaction between foreign and domestic firms that takes place within a social system, where institutions (universities, government, business) seem to matter at a macro level but not at the micro level. In other words, institutions are seen as actors that might influence the environment indirectly and ease or disturb the channels or mechanisms from where technological transfer takes place.

From the Sectoral System approach, Landini and Malerba (2016) highlight the importance of public policies aimed at strengthening local firms' capability building and promoting firms' learning as drivers of the catching-up process in an industry. Lee and Malerba (2017) identify three windows of opportunity that may emerge during the long-term evolution of an industry and modify the industry leadership; these are related to changes in knowledge and technology, changes in demand and changes in institutions and public policy. The study offers empirical evidence from six sectors and finds that in all cases a "Schumpeterian" situation is evident where exploiting a technological window is critical for emergence of new leaders in an industry.

Similarly, Malerba and Nelson (2009) highlight learning and capability building in local firms, access to foreign knowledge and productive networks, development of qualified human capital and presence of public policies as determinants of the catch-up process. The study mentions that for the case of the automotive industry, the presence and use of licenses as well as joint ventures between foreign and local firms are critical for learning and capability building of endogenous companies. For example, Brazil is mentioned as a case where multinational firms developed strong production capacities of 
their local branches and activated local procurement of parts with automotive production for the internal market.

Dutrénit, Natera, Anyul, \& Santiago (2018) argue that most catching up process has been driven by a considerable accumulation of innovation capabilities. The study highlights the investment in public goods associated with science, technology and innovation (STI) to achieve this goal for the case of Mexico. Specifically, the authors find that there is an equilibrium correcting force from STI investment to the economic growth variable and when the causality is reversed, there appears to be a driving force from economic growth and total investment on STI-related activities. The authors suggest a tragic scenario for the case of Mexico.

Another body of literature has focused on the outcomes of Kaizen training in local firms. Otsuka, Jin and Sonobe (2018) report positive outcomes from JICA's Kaizen technical assistance in Singapore, Thailand, Costa Rica, Brazil, Argentina, Paraguay, Hungary, Jordan, Tunisia, Egypt, Ethiopia, Ghana, Kenya, Tanzania, Zambia and Cameroon. The goal from the technical cooperation was to boost productivity for local small and medium enterprises. Special emphasis is set on the case of Ethiopia where a Kaizen Institute was established in 2011. The goal of the Ethiopian Kaizen Institute was to initiate and promote a country-wide quality and productivity movement and thereby boost industry competitiveness. The project was successful in training local enterprises, consultants and "trainers of trainers" that were expected to expand Kaizen activities to every region in the country. The study finds that there are eight determinants for success in Kaizen diffusion in a country: strong commitment of top leadership at different levels, the establishment of a national agenda and organizational framework with a clear vision, mission and leadership, the optimal utilization of Kaizen projects, the existence of grassroot-level promotion, the standardization and customization of training programs and materials, the development of competent consultants, the establishment of systems for awards and appreciation, and the willingness to sustain Kaizen activities after training.

Similarly, Ohno (2011) mentions that successful Kaizen practices were implemented in Singapore, Burkina Faso and Botswana. The key factors for achieving quality and productivity improvements in these countries were: a strong personal commitment of the top leader, the establishment of national organizations responsible for overlooking quality and productivity improvements, supporting institutions and mechanisms at a central and local levels, 
the diffusion of campaigns for massive participation, the creation of authorized and standardized training programs and materials and the development of private sector productivity management consultants.

Other successful cases of Kaizen adoption include the case of Iran in the public sector and oil industries (Rahmanian \& Rahmatinejad, 2013) and the case of Vietnam in the knitwear industry (Higuchi, Hoang Nam \& Sonobe, 2015). Specifically, Higuchi et al. (2015) found that for knitwear companies it took two years to assimilate and incorporate the training knowledge into the production activities; after the comprehension from local firms, an increase in value added was observed. On the other hand, the study found that for the case of the steel industry in Vietnam, Kaizen training failed to have any impacts on their business performance, which is attributed to poor design of training content with unachievable and costly intervention.

For the case of Mexico, Garcia, Rivera and Alvarado-Iniesta (2013) present results from a survey on Kaizen implementation to maquiladora companies in Ciudad Juarez, Mexico. The results indicate that education and training in operators, communication process, documentation and evaluation of project results, human resource integration, management commitment and customer focus are determinant factors for Kaizen implementation. The authors suggest that despite the results, there is no fixed recipe to implement Kaizen in Mexican firms, since companies are open systems that react differently depending on cultural, social and internal needs.

Oropesa-Vento, García-Alcaraz, Rivera, \& Manotas (2015) analyzed the effects of management commitment and the existence of work teams on Kaizen benefits of manufacturing firms in Tabasco, Sinaloa and Chihuahua, Mexico, and in Camaguey, Cuba. The study employs partial least squares and a model of structural equations to explore the benefits of implementing Kaizen practices during the planning stages of the firms. The results indicate that high levels of management commitment directly impact profits and competitiveness of firms. The organization of work teams also has competitive benefits. Kaizen is said to be critical in obtaining these success factors and allowing firms for long term sustainability of the benefits. Similarly, Oropesa-Vento, García-Alcaraz, Maldonado, \& Martinez-Loya (2016) analyze the effects of managerial commitment and the professional development of human resources on Kaizen benefits in Mexican maquiladora firms in Tabasco, Baja California, Sinaloa and Chihuahua, Mexico. The results from the study suggest that both managerial commitment and professional development and 
training of human resources are critical factors for Kaizen implementation and the variables also allow reaping the economic benefits from Kaizen after implementation. Specifically, the authors highlight the importance of human resource training since this variable record the highest impact on economic benefits from Kaizen.

\section{Empirical Methodology and Results}

The present study follows a qualitative research paradigm through explanatory case studies. The case study approach is appropriate when the issue is too complex to understand through quantitative research methods. It allows understanding the complexity of the knowledge transfer process through valuable descriptive details that can only be captured via qualitative analysis.

In total, during the PASCDM eleven local firms from Guanajuato participated in the project. From the eleven firms, JICA selected eight to do a follow-up analysis of the training effects from the project. ${ }^{5}$ From those eight firms, interviews were carried out to six of those firms (one did not accept the interview and the other closed operations) and to three Tier-1 Japanese firms vertically related with the local companies. The interviews consisted in semi-structured face-to-face interviews with the owners, directors, managers or engineers that participated during the PASCDM. The individual visits to the firms were completed in the period from January 22 to January 25, 2018. The names of the firms have been modified to comply with privacy requirements and not allow firm identification.

From the interviewed firms, five were plastic injection firms and one is dedicated to the production of bolts, screws and special fasteners. All firms are family owned and in most cases the family members are still in management positions. Interestingly, the plastic injection firms transitioned to the automotive industry from different backgrounds including the production of shoes, medical equipment, plastic bottles and food containers. The shift of production to the automotive industry was in part due to the arrival of a Japanese Tier-1 firm that encouraged several of these companies to use their plastic injection machinery and knowledge to the production of automotive parts.

5. The firm selection was decided by JICA officials, priority was given to the firms that participated in both phases of the PASCDM. 
The interviews were carried out in the production plants of the Tier-2 firms to conduct a walkthrough of the production layout and observe the changes made from the TP. The interviews were centered in three aspects of the results after the TP: positive aspects obtained after training, negative aspects after training and knowledge transfer channels and internalization and appropriation of knowledge mechanisms.

The positive aspects of the TP observed in the company visits are summarized in table 1. From the results obtained, all the participating firms mentioned that after the TP they improved their quality and productivity measurements. In terms of quality, the Kaizen and 5's methodology training was targeted to improve their quality control systems, particularly reduce their Parts per Million defective rate (PPMs). Firms before the project had their internal PPMs between $20 \%$ and $30 \%$ and this was reduced to $10 \%$ and in some cases to $1 \%$ or $0 \%$. Firms mentioned that they believed that their quality levels were acceptable before the training but realized that they were not competitive in international terms. The improvement of their quality levels opened doors to other clients and in several cases, firms expanded production. The augmentation of production however, had initial negative effects in their PPMs, since with the expansion firms saw an initial increase of their PPMs with an afterward drop once new production levels were stabilized.

\section{Table 1}

Positive Effects after the PASCDM

\begin{tabular}{c|c|c|c|c|c|c}
\hline Firm & $\begin{array}{c}\text { Quality } \\
\text { Improvements }\end{array}$ & $\begin{array}{c}\text { Industry } \\
\text { Certifications }\end{array}$ & $\begin{array}{c}\text { Productivity } \\
\text { Improvements }\end{array}$ & $\begin{array}{c}\text { Increase in } \\
\text { Customers }\end{array}$ & $\begin{array}{c}\text { Increase } \\
\text { in Sales }\end{array}$ & $\begin{array}{c}\text { New } \\
\text { Products }\end{array}$ \\
\hline $\mathrm{A}$ & $\mathrm{X}$ & $\mathrm{X}$ & $\mathrm{X}$ & $\mathrm{X}$ & $\mathrm{X}$ & $\mathrm{X}$ \\
\hline $\mathrm{B}$ & $\mathrm{X}$ & & $\mathrm{X}$ & & & $\mathrm{X}$ \\
\hline $\mathrm{C}$ & $\mathrm{X}$ & & $\mathrm{X}$ & $\mathrm{X}$ & $\mathrm{X}$ & \\
\hline $\mathrm{D}$ & $\mathrm{X}$ & $\mathrm{X}$ & $\mathrm{X}$ & $\mathrm{X}$ & & $\mathrm{X}$ \\
\hline $\mathrm{E}$ & $\mathrm{X}$ & $\mathrm{X}$ & $\mathrm{X}$ & $\mathrm{X}$ & $\mathrm{X}$ & $\mathrm{X}$ \\
\hline $\mathrm{F}$ & $\mathrm{X}$ & $\mathrm{X}$ & $\mathrm{X}$ & $\mathrm{X}$ & $\mathrm{X}$ & \\
\hline
\end{tabular}

Source: Author's elaboration from firm interviews.

In terms of productivity enhancements, the project was aimed at reducing the time needed to change their molds, what JICA refers to as the "Single Minute Exchange of Die" (SMED). The SMED training saw important results 
in time reduction in all firms of around $30 \%$ to $50 \%$ in all cases. A firm introduced magnetic platens in two of their four machines as suggested from the training. One firm in particular stands out because before the TP it had an average wait time for mold change of one to four hours and from six to twelve hours for machine cleaning and was able to reduce the indicators to 90 minutes for mold change and one hour for machine cleaning. Another firm improved their average mold changing time from 240 minutes in 2014 to only four minutes in 2017.

With respect to industry certifications, four out of six firms gained some type of certification after the PASCDM. Some of the certifications obtained are targeted to improve their manufacturing control processes such as ISO 9001:2015, ISO 9001:2018 and VDA 6.3. However, two firms also obtained the International Automotive Task Force (IATF) certification which is a technical specification specialized for the automotive industry's quality management systems. The achievement of certifications has been an important way to not only maintain competitiveness in the industry but also to present themselves as trustworthy suppliers to new clients, opening new business opportunities.

Five of the firms increased their customer base after the TP. Firms were able to increase the number of Japanese customers and clients from other nationalities, including Taiwanese, Canadian, Spanish and Mexican. This strategy was consistent in most firms as a way to minimize risk. Several firms mentioned that highlighting participation in JICA's project increased confidence to prospective customers, especially Japanese clients.

With respect to sales, four firms saw an increase in their sales volumes. Firms experienced an average annual growth in sales of 10\% to $15 \%$ from 2015 to 2017. The firms that saw a fall in sales mentioned that this was in part due to increasing difficulties with their Japanese counterparts. A firm reported a reduction of 50\% in sales between 2014 and 2017 due to a contraction in business with their Japanese client.

An important result from the TP was that the tools obtained enabled firms to develop new products in the automotive industry and expand to other markets. Firms increased their production lines and the number of plastic injection machines. Several firms mentioned that the profit margin is lower in the automotive industry than other industries and have shifted production to other markets such as shoe, household products, construction, cosmetics and medical equipment, among others. In this sense, a firm mentioned that it is considering shifting most of its production to the production of shoes 
and household products and have automotive production represent only $10 \%$ of total sales.

Despite all the positive outcomes from the PASCDM mentioned above, firms also mentioned some negative effects observed after the project. However, the negative outcomes externalized by the companies are internal or external factors that are not directly related to the TP as summarized in table 2.

\section{Table 2}

Negative Effects after the PASCDM

\begin{tabular}{c|c|c|c}
\hline Firm & $\begin{array}{c}\text { Increase in } \\
\text { Competition }\end{array}$ & $\begin{array}{c}\text { Strict Customer } \\
\text { Demands }\end{array}$ & $\begin{array}{c}\text { Employee } \\
\text { Rotation }\end{array}$ \\
\hline $\mathrm{A}$ & $\mathrm{X}$ & $\mathrm{X}$ & $\mathrm{X}$ \\
\hline $\mathrm{B}$ & $\mathrm{X}$ & $\mathrm{X}$ & $\mathrm{X}$ \\
\hline $\mathrm{C}$ & $\mathrm{X}$ & & $\mathrm{X}$ \\
\hline $\mathrm{D}$ & $\mathrm{X}$ & $\mathrm{X}$ & $\mathrm{X}$ \\
\hline $\mathrm{E}$ & $\mathrm{X}$ & $\mathrm{X}$ & $\mathrm{X}$ \\
\hline $\mathrm{F}$ & $\mathrm{X}$ & & \\
\hline
\end{tabular}

Source: Author's elaboration from firm interviews.

The main external factor affecting the firms is an increase in competition in the industry. It was argued that in 2014 there were only three suppliers for a specific Japanese Tier- 1 firm and by 2017 the figure jumped to ten firms. The arrival of competing firms has not been only of Mexican origin but also from countries such as Germany, Korea, U. S., and Spain. The presence of new firms has pressured them to further QCD improvements and has also put strains in the current labor market, increasing employee rotation.

Another external factor mentioned by four firms is strict customer demands associated to a Japanese Tier-1 customer. The firms signaled that a specific Japanese client has implemented a "peso policy" where exchange rate fluctuations that might result in an increase of production costs has to be absorbed by the Tier- 2 firm. This has affected the long-term relationship perception with this client and pushed firms to seek diversification to new customers.

An important internal factor affecting all but one of the firms is employee rotation. Firms mentioned that they are facing a labor shortage in the region and that high employee rotation has difficulted the internalization and 
absorption of the TP knowledge since resources are wasted in training new workers. Firms also blame the employee rotation in the shoe industry tradition engraved in Guanajuato, where the system of production and piecework labor has difficulted worker adaptation to the automotive industry's type of production. The firm that has not been affected by employee rotation mentioned that this is due to the fact that they are installed in a small town and the majority of workers come from the same community. They mentioned that they have had up to three generations of a family working for the company.

Overall, firms mentioned that the PASCDM successfully transmitted knowledge related to Japanese production, quality and organization systems. As shown in table 3 , in all cases tacit and explicit knowledge was transferred from the project. In terms of tacit knowledge, firms learned "know-how" that improved their quality and productivity indicators. Explicit knowledge or what is referred to as "know-that" was also transferred via training manuals and helped further understanding of the Kaizen philosophy. In terms of internalization and absorption of knowledge, all firms were able to appropriate the explicit knowledge but only half were able to internalize the tacit knowledge. The internalization mechanisms followed by the local firms were workflow and information diagrams, manuals, checklists and training programs. In all cases the transfer channel was an informal kind through local supplier training. Interestingly, the majority of the firms experienced intrafirm knowledge spillovers, meaning that the Kaizen training was employed in other production lines within the companies. In one particular case the knowledge had spilled over to a sister company of a trained firm that has adopted Japanese productions systems. 
Table 3

Knowledge Transfer and Spillovers from the PASCDM

\begin{tabular}{l|l|l|l|l|l|l|l}
\hline Firm & Tacit & Internalized & Explicit & Internalized & $\begin{array}{l}\text { Knowledge } \\
\text { Internalization } \\
\text { Mechanisms }\end{array}$ & $\begin{array}{l}\text { Transfer } \\
\text { Channels }\end{array}$ & $\begin{array}{l}\text { Knowledge } \\
\text { Spillovers }\end{array}$ \\
\hline A & Yes & Partially & Yes & Yes & $\begin{array}{l}\text { Workflow } \\
\text { diagrams, } \\
\text { manuals }\end{array}$ & Informal & $\begin{array}{l}\text { Other } \\
\text { product } \\
\text { lines }\end{array}$ \\
\hline B & Yes & No & Yes & Yes & $\begin{array}{l}\text { Information } \\
\text { diagrams, } \\
\text { manuals }\end{array}$ & Informal & $\begin{array}{l}\text { Other } \\
\text { product } \\
\text { lines }\end{array}$ \\
\hline C & Yes & No & Yes & Yes & $\begin{array}{l}\text { Checklists, } \\
\text { operation } \\
\text { sheets, } \\
\text { manuals }\end{array}$ & Informal & No \\
\hline D & Yes & Yes & Yes & Yes & $\begin{array}{l}\text { Information } \\
\text { diagrams, } \\
\text { manuals }\end{array}$ & Informal & $\begin{array}{l}\text { Other } \\
\text { product } \\
\text { lines }\end{array}$ \\
\hline E & Yes & Yes & Yes & Yes & $\begin{array}{l}\text { Information } \\
\text { diagrams, } \\
\text { checklists, } \\
\text { manuals }\end{array}$ & Informal & $\begin{array}{l}\text { Other } \\
\text { product } \\
\text { lines }\end{array}$ \\
\hline F & Yes & Yes & Yes & Yes & $\begin{array}{l}\text { Checklists, } \\
\text { manuals, } \\
\text { training } \\
\text { programs } \\
\text { other } \\
\text { companies }\end{array}$ \\
\hline lines, \\
product
\end{tabular}

Source: Author's elaboration from firm interviews.

To confirm the validity of results from the interviews, the case studies included visits to the Japanese customers of the trained Mexican firms. The Japanese Tier-1 firms rank their suppliers on an A to $Z$ scale. This evaluation considers quality throughout the production process, results from audits and quality supplier development programs, the measurements of their PPMs and Key Performance Indicators (KPIs). One of the firms mentioned that suppliers must meet the criteria related to their QCDDM (Quality, Costs, Delivery, Development and Management). Table 4 summarizes the rank obtained from the Mexican Tier- 2 firms before and after the PASCDM. 
Table 4

Supplier Rank Before and After the PASCDM

\begin{tabular}{|c|c|c|c|c|c|c|c|c|c|c|c|c|}
\hline \multirow{3}{*}{$\begin{array}{l} \\
\begin{array}{l}\text { Japanese } \\
\text { Firm }\end{array}\end{array}$} & \multicolumn{12}{|c|}{ Mexican Supplier Firm } \\
\hline & \multicolumn{2}{|c|}{$A$} & \multicolumn{2}{|c|}{$B$} & \multicolumn{2}{|c|}{ C } & \multicolumn{2}{|c|}{$D$} & \multicolumn{2}{|c|}{$E$} & \multicolumn{2}{|c|}{$F$} \\
\hline & $\frac{0^{2}}{\infty}$ & $\underbrace{\grave{2}}_{\frac{\pi}{4}}$ & $\frac{\square}{\stackrel{\nu}{\nu}}$ & $\frac{\bar{\pi}}{\mathbb{L}^{2}}$ & $\frac{\frac{2}{2}}{\frac{0}{2}}$ & 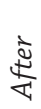 & $\frac{\frac{0}{2}}{\frac{0}{2}}$ & 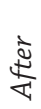 & $\frac{\stackrel{0}{0}}{\infty}$ & 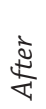 & $\frac{\grave{c}}{\infty}$ & 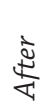 \\
\hline 1 & / & l & C & D & C & B & D & D & $\mathrm{F}$ & C & I & l \\
\hline 2 & I & I & I & / & I & / & / & / & N/A & $\mathrm{A}$ & N/A & A \\
\hline 3 & C-D & B & / & / & l & / & / & l & / & / & / & / \\
\hline
\end{tabular}

Source: Author's elaboration from firm interviews.

Firm J1 has employed four of the six Mexican firms interviewed. According to the company Director and quality manager, firms $C$ and $E$ improved their supplier rank after the PASCDM, while firm $D$ remained in the same position and firm B worsen their standing. Overall, the firm argued that firms that received training improved their understanding of Kaizen and 5's philosophy; however, it was also highlighted that the industry currently requires them to be trained in more advanced tools such as Monozukuri. ${ }^{6}$ This firm mentioned its commitment for supplier development through technical guidance and support expecting to increase their local supplier base and local procurement content.

Firm J2 started working with firms E and F after the PASCDM, but it considers both of them A-type suppliers. However, firm F is considered a "major" supplier while firm E is a "regular" supplier. Firm J2 mentioned that it maintains a close relationship with their suppliers to provide support via regular audits and the set-up of schemes to help firms meet cost-reduction targets. This firm also acknowledged the importance of learning Monozukuri techniques to successfully reduce the knowledge and cultural gap between Mexican and Japanese companies. The company indicated that it has set forward strategies to increase local content from $75 \%$ to $90 \%$ in the next couple of years where Mexican companies are expected to play an important role.

6. The term "Monozukuri" depicts the process of Japanese manufacturing process. It includes not only the technological and know-how aspects of the process but also the spirit related the pursuit of innovation and perfection in the activities of craftsmanship and manufacturing. 
Firm J3 has dealings with firm A. They considered this firm to be in the C-D range of supplier rank before the project and improved to a B-type of supplier after. The firm works with a core of 4 Tier-2 companies where firm A is the only Mexican owned firm. It was argued that after the Kaizen training the firm understood that it had to evolve to survive in the industry and it became a "thinking" entity. Despite the positive growth, J3 firm believes that there is still room for further improvements especially in terms of cost competitiveness. The firm implemented a one-year project to help further develop supplier A with improvements in their mold maintenance abilities and production floor layout. They currently program four annual visits to the plant to plan new activities for further improvements.

\section{Discussion and Conclusions}

Developing countries have struggled to promote their automotive industry due to the stiff requirements of skilled labor and a lack of a technologically capable supporting industry. It has been argued that the automotive industry brings positive externalities from a vertically integrated production chain, but it seems to take time for local firms to obtain these benefits since local companies require a process of knowledge and capability accumulation. This process may be shortened via training.

Training is considered an informal channel of knowledge transfer that transmits both tacit and explicit knowledge. For the case of the automotive industry, the transfer of tacit knowledge is crucial for organizational learning and development. This type of knowledge is acquired by learning-by-doing and trial and error experience.

For the case of Japanese FDI, linkages with local firms may be limited due to the particular characteristics of following a keiretsu-type of global-local interlinked network that favors input procurement from companies that form part of the same business group. An additional barrier for local firms is the technological gap that impedes them from achieving the required quality, costs and delivery times. Furthermore, the catching-up process depends on industry, institutional and firm-level capabilities. Training may improve in the short-run firm-level capabilities and if knowledge is diffused to other firms, it may impact the industry-level and institutional settings in the long-run.

The catching up of local firms depends on necessary conditions where government training programs play an important role. However, Hoshino 
(2015) mentions that for local firms to catch-up and eventually enter global production networks in the automotive industry the most important and crucial condition is related to internal willingness and capability building of the endogenous firms. For the case of Mexico, it has been argued there are still strong barriers for local firms to establish production chain relations with foreign firms. Primarily, local firms still need to catch-up in terms of quality and reduce the business and cultural gaps between them and their Japanese counterparts, especially with regards to the unawareness of the Japanese culture in general and of the Japanese production system in particular. Furthermore, local firms lack information and business encounter opportunities to establish themselves as reliable suppliers. It has been argued that institutions might affect the transfer of knowledge to domestic firms at the macro-level, but little emphasis has been set at the micro-level. This analysis provides evidence that institutions such as government agencies may affect the transfer of knowledge to local firms at the micro-level via training.

In this sense, from the cases analyzed, the introduction of Japanese Production Systems has enabled local firms to acquire process and in some cases functional upgrading; however there is still a need for firms to catch-up in terms of product and design upgrading. This seems as a difficult task in the automotive industry, where the fierce competition compels all firms to continuously improve their production processes in order to enhance their efficiency and productivity allowing them to meet cost containment targets while achieving high product quality (Pavlinek \& Zenka, 2011). On the other hand, product and design upgrading appears to take place more selectively, limited to multinational firms in higher tiers of the supplier chain. Giuliani, Pietrobelli and Rabelloti (2005) have shown this to be the case for Latin American contexts, where "innovation" is seen more as a pattern of learning, provided that local firms tend to adapt and incrementally improve, rather than create new knowledge and technology. The main challenges for local automotive suppliers in Mexico lie in a first stage in productivity improvements that will allow them to be cost competitive and apt in terms of quality as the international market demands; and in a later stage the transition to innovative and design activities within Mexico. In a country that records public R\&D investment at $0.6 \%$ of GDP, while similar economies invest over $4 \%$ of GDP (Global Business Reports, 2016), it becomes highly relevant to stimulate this investment to boost innovative activities. 
JiCA has offered TPs to developing countries in a wide array of areas, seeking impacts at the organizational level. The PASCDM stands out as one of JICA's ODA programs in Mexico created to strengthen and develop the local supplier base in the automotive industry via training. The training consisted primarily in the dispatch of Japanese experts to the production plants to offer technical support and transmit Kaizen philosophy to the participating firms. The project was carried out from November 2012 to November 2015 in the sates of Queretaro, Guanajuato and Nuevo Leon with the inclusion of state governments and federal government development agencies. In total, 30 firms participated in the PASCDM, including eleven firms from Guanajuato.

In this study, interviews were carried out with six of the participating Tier-2 firms from Guanajuato and with three Tier-1 Japanese firms that have business relations with the trained Mexican companies. The interviews consisted in semi-structured face-to-face interviews with key participants of the PASCDM. The objective of the study consisted in the analysis of the impact of the project in terms of benefits and struggles observed after the TPs and the mechanisms implemented within the organization to internalize the newly acquired knowledge.

The PASCDM successfully transmitted tacit and explicit knowledge related to Japanese production, quality and organization systems. Firms learned "know-how" that improved their quality and productivity indicators and "know-that" that helped further understanding of the Kaizen philosophy. All firms were able to internalize and absorb the explicit knowledge but only half were able to internalize the tacit knowledge due to employee rotation. Firms used workflow and information diagrams, manuals, checklists and training programs to capture the learning from training. In all cases the transfer channel achieved via local supplier training. The majority of the companies were able to transmit the knowledge to other sections of the organization, primarily to other production lines, evidencing intra-firm knowledge spillovers. One particular firm was able to transmit the Kaizen knowledge to a sister company that now also follows a Japanese-type of production system.

The main findings from the interviews to local firms show clear benefits from participating in the PASCDM. Firms report that from the TPs they acquired a better understanding of the expectations from Japanese customers. Through training the firms gained Kaizen knowledge, implemented 5's methodologies, standardized their work flow instructions helping them to improve their quality control systems. This helped improve their quality 
requirements by reducing their PPMs. Also, time reductions were achieved in mold changing, machine cleaning, and material rotation. Overall, trained companies have seen improvements in their productivity and KPIs. After the project, firms have also searched for certifications such as ISO, IATF and VDA in different versions. The improvements achieved are reflected in overall company growth and market diversification, with several firms expanding production to new customers, industries and countries. Another important benefit from participation in the PASCDM is that local firms that highlight JICA training seem to give them an advantage with potential customers by increasing confidence for future business endeavors.

Despite the benefits before mentioned, local firms also mentioned several struggles. The firms are facing fierce competition in the industry that brings pressure in the labor market for human capital. This results in labor shortage problems and high employee rotation bringing an additional situation of wasted resources in new-employee training. Several firms also mentioned difficulties in their dealings with their Japanese customers. In particular, several firms mentioned that a Japanese client has pushed them for excessive cost reductions and implemented a "peso policy" to deal with exchange rate fluctuations that only favors the Japanese company.

For local firms, there are still opportunities to enter the Japanese production chains at the Tier- 2 and Tier-3 levels of procurement, since more than half of these inputs are still imported, and the industry is demanding higher levels of local content. However, fierce competition is growing in the industry, with more arrival of Tier-2 firms from the U. S., Spain, Germany, Korea and Taiwan so local supplier firms must continue to improve their quality, costs and delivery times to remain competitive against foreign firms. Also, uncertainty in the NAFTA negotiations has reduced production from OEMs and this may in turn bring further pressure along the production chain. Despite this, according to the interviews, there is a growing market for plastic mold maintenance services, fabrics, internal painting, chrome plating, die casting and stamping where local firms may participate. However, Mexican firms must also insert themselves into activities with higher value added related with design and innovation.

For the case of Japanese Tier- 1 companies, the results of the interviews showed that training from the PASCDM gave the Mexican firms the tools to implement Kaizen and 5's philosophy but there is still room for major improvements. Trained firms advanced their QCD levels and this resulted in a 
growth in orders from their Japanese clients. However, Japanese companies emphasized the need for training in Monozukuri, a more advanced tool that fits the industry's current needs. Also, the development in QCDDM (Quality, Costs, Delivery, Development and Management) is encouraged. The Japanese companies interviewed seem committed to continue training and supplier development with Mexican firms, they currently offer in-house training, provide routinely visits and audits to the companies to provide feedback and help them keep on track. The Japanese firms manifested interest in working alongside JICA in human capital and local supplier development; they see the efforts from JICA as crucial in improving local input procurement in the industry and deal with the labor shortage problem.

The overall results from JICA's PASCDM show interesting and positive outcomes. Firms seem committed to continue applying the knowledge received and most of them are eager to continue training in the future. The firms interviewed propelled the organization of the Guanajuato Automotive Cluster (CLAUGTO in Spanish) and actively participate in activities that promote improvements in their manufacturing processes. One Tier- 2 interviewee signaled: "For Mexicans it has been hard to adapt and accustom (to Kaizen), these are the best practices and we have to change our idiosyncrasy to be able to adopt them, they are needed in any type of organization. We hope this is the road to our success". A Japanese director argued that projects such as the PASCDM are important, but it should be the task of Mexico to carry them out, "Mexico should not continue being a place for cheap production and Mexican companies need to be inserted in the global production value chains".

Future JICA projects in the region may bring further benefits for the automotive industry in general and to local automotive supplier development and human capital formation in particular. The "Project for Automotive Cluster Promotion in Mexico" and the "Project for Human Resource Development for the Automotive Industry in El Bajio of Mexico" seem committed to achieve these goals. A company director from a Japanese firm mentioned that "there are previous experiences from other countries in human resource development, but only Japanese are interested in developing Mexican suppliers"; therefore, Mexican firms must take advantage from these training opportunities to develop capabilities required in global production chains. Future research is encouraged to analyze the impacts of these new projects and document replicable strategies for other regions and other industries in Mexico. mp 


\section{References}

Acemoglu, D. (1997). Training and Innovation in an Imperfect Labour Market. Review of Economic Studies, 64(3), 445-464. doi: 10.2307/2971723

Acemoglu, D., \& Pischke, J. (1998). Why do Firms Train? Theory and Evidence. The Quarterly Journal of Economics, 113(1), 79-119. doi: 10.1162/003355398555531

Almeida, R., \& Carneiro, P. (2009). The Returns to Firm Investments in $\mathrm{Hu}-$ man Capital. Labour Economics, 16(1), 97-106.

Athukorala, P., \& Kohpaiboon, A. (2011). Thailand in Global Automobile Networks. Switzerland: International Trade Center.

Bartel, A. P. (1994). Productivity Gains from the Implementation of Employee Training Programs. Industrial Relations, 33(4), 411-425. doi: 10.1111/j.1468-232X.1994.tb00349.x

Boom, A. (2005). Firms' Investment in General Training and the Skilled Labour Market. Labour Economics, 12(6), 781-805. doi: 10.1016/j.labeco.2004.03.003

Chen, Y., Hsu, J., \& Huang, M. (2013). Lagged Effects of Training on Financial Performance: Evidence from Longitudinal Data. Global Journal of Business Research, 7(1), 9-20.

Dumas, A., \& Hanchane, S. (2010). How Does Job-training Increase Firm Performance? The Case of Morocco. International Journal of Manpower, 31(5), 585-602.

Dutrénit, G., Natera, J., Anyul, M., \& Santiago, F. (2018). Pro-Cyclical Dynamics of STI Investment in Mexico. In J. Niosi (Ed.), Innovation Systems, Policy and Management. Cambridge: Cambridge University Press, 217248. doi:10.1017/9781108529525.009

Fujimoto, T. (2007). Competing to Be Really, Really Good: The Behind-the-Scenes Drama of Capability-Building Competition in the Automobile Industry. Japan: International House of Japan.

Garcia, J. L., Rivera, D. G., \& Alvarado-Iniesta, A. (2013). Critical Success Factors for Kaizen Implementation in Manufacturing Industries in Mexico. The International Journal of Advanced Manufacturing Technology, 68(1-4), 537-545. doi: 10.1007/s00170-013-4750-2

Giuliani, E., Pietrobelli, C., \& Rabelloti, R. (2005). Upgrading in Global Value Chains: Lessons from Latin American Clusters. World Development, 33(4), 549-573. doi:10.1016/j.worlddev.2005.01.002 
Global Business Reports. (2016). Mexico's Regional Automotive Report 2016. Singapore: Global Business Reports. Retrieved from https://www. gbreports.com/wp-content/uploads/2016/09/Mexico-Automotive2016-web-v2.pdf

Guzman-Anaya, L. (2018). The Impact of Japanese Training Programs on the Productivity of Local Automotive Suppliers in Guanajuato, Mexico. In M. Falck-Reyes and L. Guzman-Anaya, ed., Japanese Direct Investment in Mexico's Transport Equipment Sector: Macro Impact and Local Responses. Singapore: Springer, 103-133. doi: 10.1007/978-981-10-7718-0

Higuchi, Y., Nam, V. \& Sonobe, T. (2015). Sustained Impacts of Kaizen Training. Journal of Economic Behavior \& Organization, 120, 189-206. doi: 10.1016/j.jebo.2015.10.009

Hoshino, T. (2015). Boundaries of Firms and Catching Up by Latecomers in Global Production Networks: The Case of a Mexican Auto-Parts Manufacturer. IDE Discussion Paper, 492.

Hosono, A. (2015). Industrial Transformation and Quality of Growth. JICA-RI Working Paper, 97. Retrieved from https://www.jica.go.jp/jica-ri/publication/workingpaper/industrial_transformation_and_quality_of_growth. html

Huang, T. C. (2001). The Relation of Training Practices and Organizational Performance in Small and Medium Size Enterprises. Education + Training, 43(8/9), 437-444.

Imai, M. (1986). Kaizen: The Key to Japan's Competitive Success. New York: McGraw-Hill.

Irawati, D. (2012). Knowledge Transfer in the Automobile Industry. Great Britain: Routledge.

Japan International Cooperation Agency (JICA). (2016). JICA Activities in Mexico. Retrieved from: http://www.jica.go.jp/mexico/english/activities/ index.html. Accessed: March 10, 2018.

Japan International Cooperation Agency (JICA). (2017). JICA 2017 Annual Report. Retrieved from: https://www.jica.go.jp/english/publications/ reports/annual/2017/c8h0vm0000bws721-att/2017_all.pdf Accessed: March 28, 2018.

Kijima, Y. (2018). Long-term and Spillover Effects of Rice Production Training in Uganda. JICA-RI Working Paper, 161. 
Lee, K., \& Malerba, F. (2017). Catch-up cycles and Changes in Industrial Leadership: Windows of Opportunity and Responses of Firms and Countries in the Evolution of Sectoral Systems. Research Policy, 46(2), 338-351.

Landini, F. and Malerba, F. (2016). Public Policy, Catching Up in Global Industries and Technological Change: A Simulation Model. Milan: Bocconi University.

Lugo-Sanchez, M. G. (2018). The Role of Public Policies in Attracting Japanese FDI in Mexico. In M. Falck-Reyes and L. Guzman-Anaya, ed., Japanese Direct Investment in Mexico's Transport Equipment Sector: Macro Impact and Local Responses. Singapur: Springer, 81-101. doi: 10.1007/978-98110-7718-0

Malerba, F. (2018). Moving Forward in Sectoral Systems Research. In J. Niosi, ed., Innovation Systems, Policy and Management. Cambridge: Cambridge University Press, 27-52. doi: 10.1017/9781108529525.003

Malerba, F. \& Nelson, R. (2009). Sistemas Sectoriales, alcance y desarrollo económico. Economía: Teoría y Práctica, 1, 41-62.

Mikami, S. \& Furukawa, M. (2014). An Empirical Study of the Conditions for Successful Knowledge Transfer in Training Programs. JICA-RI Working Paper, 85.

Nakano, Y., Tsusaka, T. W., Aida, T., \& Pede, V. O. (2015). The Impact of Training on Technology Adoption and Productivity of Rice Farming in Tanzania: Is Farmer-to-Farmer Extension Effective? JICA-RI Working Paper, 90.

Nikandrou, I., Apospori, E., Panayotopoulou, L., Stavrou, E. T., \& Papalexandris, N. (2008). Training and Firm Performance in Europe: The Impact of National and Organizational Characteristics. The International Journal of Human Resource Management, 19(11), 2057-2078.

Nonaka, I. \& Takeuchi, H. (1995). The Knowledge Creating Company. How Japanese Companies Create the Dynamics of Innovation. New York: Oxford University Press.

Nonaka, I., Toyama, R., \& Nagata, R. (2000). A Firm as the KnowledgeCreating Entity: A New Perspective on the Theory of the Firm. Industrial and Corporate Change, 9(1), 1-20.

Ohno, I. (2011). National Movements and the Synthesis of Selected Country Experiences. In Kaizen National Movements, a Study of Quality and Productivity Improvements in Asia and Africa. Tokyo: JICA-GRPIS.

Oropesa-Vento, M., García-Alcaraz, J. L., Maldonado, A. A., \& Martinez-Loya, V. (2016). The Impact of Managerial Commitment and Kaizen Benefits 
on Companies. Journal of Manufacturing Technology Management, 27(5), 692-712.

Oropesa-Vento, M., García-Alcaraz, J. L., Rivera, L., \& Manotas, D. F. (2015). Effects of Management Commitment and Organization of Work Teams on the Benefits of Kaizen: Planning Stage. DYNA, 82(191), 76-84.

Otsuka, K., Jin, K., \& Sonobe, T. (2018). Applying the Kaizen in Africa. A New Venue for Industrial Development. Switzerland: Palgrave Macmillan.

Rahmanian, F., \& Rahmatinejad, Z. (2013). Impact of Kaizen Implementation on Performance of Manufacturing Companies' Staff. European Online Journal of Natual and Social Sciences, 2(1), 1094-1103.

Pavlinek, P., \& Zenka, J. (2011). Upgrading in the Automotive Industry: Firm-level Evidence from Central Europe. Journal of Economic Geography, 11, 559-586.

Rivera, M. I. (2002). Technology Transfer Via University-Industry Relationship. New York: Routledge Falmer.

Sahoo, P., \& Bishnoi, A. (2016). Role of Japanese Official Development Assistance in Enhancing Infrastructure Development in India. Contemporary South Asia, 24(1), 50-74.

Secretaría de Economía (SE). (2018). Registro Nacional de Inversiones Extranjeras. Retrieved from https://datos.gob.mx/busca/dataset/registronacional-de-inversiones-extranjeras-rnie

Smitka, M. J. (1991). Competitive Tie: Subcontracting in the Japanese Automotive Industry. United States: Columbia University Press.

Tessema, M., Winrow B., \& Teclezion, M. (2012). The Transfer of Training at Macro Level in Least Developing Countries: A Case Study of the "Brain Drain" in Eritrea. International Journal of Training and Development, 16(4), 247-262.

United Nations Conference on Trade and Development (UNCTAD). (2014). Facilitating Transfer of Technology to Developing Countries: A Survey of Home-County Measures. United States: United Nations.

Urata, S. (1996). Japanese Foreign Direct Investment and Technology Transfer in Asia. MIT Japan Program Working Paper Series, 96-23.

Yamashita, S. (2004). Development of Automobile Parts Industry and Formation of Export Platform in Thailand. International East Asia Research Center, ASEAN-Auto Project, 4(1). 